\title{
eLearning at Czech Engineering Universities in 1998 - 2013
}

\author{
Petra Poulova Ivana Simonova Miloslava Cerna
}

University of Hradec Kralove, Faculty of Informatics and Management

\begin{abstract}
At the beginning of this millennium the European Commission announced eLearning to be a strategic plan for developing new trends in gradual and lifelong education. Analogous to other European countries also in the Czech Republic strong emphasis was put on education, particularly on improving competences in the field of ICT. These tendencies are strongly reflected in engineering education. Despite the starting problems in the last decade, eLearning has become a standard within the tertiary education. The eLearning forms of instruction at universities can be used in both gradual study programmes and lifelong education.
\end{abstract}

Keywords: eLearning, eLearning polices, infrastructure, Learning Management System, research, university education

\section{Introduction}

The strategy of European Union in the field of education since the end of the 20th century has been characterized by the emphasis on the development of key competences, mainly in the field of the information and communication technologies (ICT) and foreign languages. This strategy has been defined by several important documents prepared by European Commission, e.g. [1], [2], [3]; etc.

Similarly the Czech educational system also underwent substantial changes in the last decades. The ICT-supported distance form of education appeared in the Czech educational system after 1990. These approaches quickly penetrate the lifelong education but can be easily applied in the present form of study at educational institutions of all levels. [4]

Information technology, particularly the computer support in education has been widely and frequently applied, researched and evaluated for last two decades. During quite a short fifteen-year history the term of eLearning has not been defined exactly. It depends on the author's view which features are emphasized. Differentiated views are caused by a wide range of the field and influenced by the environment in which and how it is applied.

Some authors emphasize a technological approach to eLearning. They understand it as a tool for designing, updating, distribution and evaluation of the process of instruction, knowledge management run by net technologies and computers with appropriate hardware and software equipment. Other authors emphasize multimediality of eLearning, and another approach emphasizes eLearning in computer networks and on the Internet.

The pedagogic (didactic) approach provides another view. eLearning is understood as such a way of instruction which uses information and communication technologies to managing the whole process, designing courses, distributing study content, communication between students, teachers. [5]

As it is obvious from the above mentioned definitions, eLearning is approached from two main directions. First, 
it is an educational process which uses information and communication technologies. Second, it is understood as a set of technological tools applied in education. In the wide context, eLearning is the educational process supported by information and communication technologies. Computer applications integrate single elements, combine explanations in the text form with animations, simulations, graphics, diagrams, audio and video recordings, electronic tests. Students can choose the way which suits best their individual preferences. [6] eLearning includes not only educational systems available on the computer networks but also educational software on portable media (CDs, DVDs).

Last but not least, Logan defines eLearning as follows: "The " $\mathrm{e}$ " doesn't stand for electronic. Better to think of the " $\mathrm{e}$ " as evolving, or everywhere, or enhanced or extended ... and don't forget effective".

\section{2. eLearning at Czech universities}

eLearning can be applied in the distance study programmes, in the part-time study programmes or to support present lessons (blended learning).

A wide range of agreement and disagreement with new educational approaches could be seen both across the whole system and insight the single institutions. [5]

The process of eLearning implementation could be structured into three basic steps: [8]

First, getting new hardware, software and other class equipment was essential. In real life new computers and programmes were bought, classrooms equipped with data projectors and special computer furniture (tables, chairs) which are user-friendly and do not damage health after long hours of sitting in front of the computer.
Second, forming general media competence followed. It means that all possible participants of the process had to learn how to work with computers and become computer literate, which covers academic, technical and administrative staff of the faculty, and students. Current understanding of what the expression media competence really means is explained from the point of basic computer literacy, which covers the use of computers and information and communication technologies. Knowledge management, i.e. the strategy how to work with information, gain and process it, apply in professional work, is closely related to it.

Third, applying the general computer literacy in education which is the most difficult and demanding part, crucial for the process of education. It covers didactic training aimed at both teachers and students so that they know how to teach and study being supported or managed by ICT.

At the very beginning of this process, Step Zero was usually introduced at several universities which meant e.g. presenting study materials in shared directories, using e-mail for communication between teachers and students, creating university web pages, editing electronic journals etc. [7]

\section{The process of eLearning imple- mentation at Czech engineering universities}

In 2009 - 2012 academic years the research team of the University of Hradec Králové solved several projects dealing with eLearning. One of the partial projects focused on the process of its implementation at Czech universities. [8], [9],

In 2012 twenty-six public universities have been accredited in the Czech Republic, two state colleges and more than 45 private (non-state) ones. Although the number of private colleges is twice higher 
than state universities, only few per cent of students are enrolled. Number of students and short tradition are the main reasons why only public universities were included in the research. Annual reports of Czech public universities from 1999 to 2012 were the main source of information.

The research sample contained annual reports of single universities published in 1999 - 2012. In total, more than 250 annual reports were included in the research. Information on eLearning was searched, both in the form of single chapters and in the data mentioned in the text.

Despite the engineering education is provided by most of Czech universities, only following eleven ones run substantial deal of it and were included in the research sample.

- Brno University of Technology (VUT),

- College of Polytechnics, Jihlava (VŠPJI),

- College of Technology and Economics, České Budějovice (VŠTE),

- Czech Technical University, Prague (ČVUT),

- Czech University of Life Sciences,

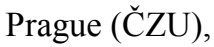

- Institute of Chemical Technology, Prague (VŠCHT),

- Mendel University, Brno (MENDELU),

- Technical University of Liberec (TU),

- University of Economics, Prague (VŠE),

- University of Pardubice (UPCE),

- VŠB-Technical University of Ostrava (VŠB-TU).

\subsection{Chronological development of eLearning implementation}

An electronic support of instruction first appeared in 1999 university annual report.

In 2000 eLearning emerged in University of Economics, Prague. V̌̌E de- scribed their eLearning project, they planned to design a course for academic staff on LMS WebCT and LearningSpace, One year later, in 2001, eLearning was mentioned in annual reports of these engineering educational institutions:

ČVUT described ICT integration into educational parts of strategic long-term plan and eLearning pilot projects,

VŠB-TU prepared study materials for part-time and present form of study on university website.

VŠE prepared the distance form of master study programme in eLearning form and organized training for academic staff,

VŠCHT built a virtual library of electronic study materials on university websites.

The MENDELU states no eLearning activities in the institution. Other universities do not mention eLearning at all.

In 2002 the number of engineering educational institutions using eLearning substantially increased again. ČZU, TU, MENDELU, joined the eLearning community and made some references to eLearning in their annual reports.

Since 2003 eLearning has been mentioned in annual reports of most universities.

\subsection{Academic staff education}

Successful eLearning implementation takes paying attention to academic staff education in the field of new methods, both from the technical point of view, and pedagogy and didactics. This fact is crucial mainly in relation of engineering pedagogy because their academic staffs usually are excellent specialists in their field but hardly any education in pedagogy, as well as in didactics and branch didactics. In some cases they are limited by lack of knowledge and experience in using ICT in the process of instruction. That is why universities often present ways and results of process methodologi- 
cal support to eLearning in their annual reports.

The first mentioned training of academic staff in methodology of the distance education can be found in 2000 annual report of V̌SE presenting the fact a course for teachers will be prepared focusing on methodology of designing an online subject supported by WebCT and LearningSpace technologies.

Two year later, in 2002, other three universities joined this forward-looking group - ČVUT, ČZU and VŠB-TU.

Most universities mentioned the academic staff training in methodology of the distance online and e-supported instruction.

\section{Conclusion}

In previous chapters of the paper basic facts on the process of eLearning implementation at Czech public universities focusing on engineering education were presented and summarized. The provided facts verify the statement eLearning had spread to most universities in the Czech Republic and had become standard, as it was in other developed educational systems.

The whole Middle- European Region underwent similar development in the field of university education in last several years. As the facts prove, in the last decade eLearning became a common approach to university education. Having spent the quantitative and qualitative development, further improvements in quality are expected by using modern technologies and/or social networks

\section{References}

[1] European Commission. Growth, competitiveness, and employment. The challenges and ways forward into the 21st century. Brussels: European Commission, 1993.
[2] European Commission. White Paper on Education and Training - Teaching and Learning - Towards the Learning Society. Brussel: European Commission, 1995.

[3] European_Commission. The eLearning Action Plan: Designing tomorrow's education. Brussel: European Commission, 2001.

[4] Šimonová, I., "Learning styles in foreign language instruction" Interactive collaborative learning (ICL2011) 11th International Conference Virtual University, VU'11, pp. 595-601, 2011

[5] Šimonová, I., Poulová, P., Šabatová, M., Bílek, M., Maněnová, M. On Contribution of Modern Technologies Towards Developing Key Competences. Hradec Králové : M. Vognar. 2009.

[6] Šimonová, I., Bílek, M. "The distance learning. Comparative students' evaluation in 2005 - 2010: example of University of Hradec Kralove". $e$ Learning : proceedings of the 9th European conference. Reading : Academic publishing, 2010, pp. 571 - 577.

[7] Šimonová, I. "Learners' experience in LMS in 2001 - 2010: case study". Applied computer science : international conference. Athens : World scientific and engineering academy and society, 2010, pp. 464-469.

[8] Poulová, P., Šimonová, I. “eLearning at Czech universities in 1999 - 2010". e-Learning : proceedings of the 9th European conference. Reading : Academic publishing, 2010, s. 512 - 520.

[9] Poulová, P., Šimonová, I. "The traditional versus ICT-supported instruction within the tertiary education: comparative study". In $i$-Society 2011 : international conference : proceedings, London, pp. 321-326. 